\title{
ANALISIS FAKTOR YANG MEMPENGARUHI PENYERAPAN TENAGA KERJA DI PROVINSI JAMBI
}

\author{
Muhammad Syafri ${ }^{1}$, Zulfanetti ${ }^{2}$
}

\begin{abstract}
Jambi Province is one of the areas in Indonesia with a relatively high population growth is inseparable from the problem of employment. Problems encountered include increased workforce higher than labor absorption. Efforts to increase labor absorption can not be separated from influencing factors such as GRDP, provincial minimum wage, government expenditure. This study aims to analyze the effect of GRDP, Province Minimum Wage, Government Expenditure on Employment Absorption in Jambi Province during the period of 1997-2015. This research is expected to be used as one of the benchmarks for government and private sector to better pay attention to the level of employment in Jambi Province. The type of research used is descriptive quantitative with used secondary data and analysis by time series data, from 1997 to 2015 and used the Ordinary Least Square (OLS) regression analysis with the help of EVIEWS 9.0 software. The result of this research shows that partially PDRB variable in PDRB has significant effect to the absorption of manpower in Jambi Province. While the variables of UMP and Government expenditure did not affect the absorption of manpower in Jambi Province period 1997 - 2015. The coefficient of determination $\left(R^{2}\right)$ showed that the independent variables studied were able to explain 91 percent of labor absorption and the remaining 9 percent was explained by other variables not studied.
\end{abstract}

Keywords: Employment Absorption, GRDP, UMP and Government expenditure

\section{PENDAHULUAN}

Masalah ketenagakerjaan yang dihadapi oleh Indonesia adalah pesatnya peningkatan jumlah angkatan kerja disetiap tahunnya. Khususunya di Provinsi Jambi, merupakan provinsi yang memiliki jumlah penduduk cukup besar, dengan menduduki peringkat ke4 di Sumatera yakni 3.168.637 jiwa.

Jumlah tenaga kerja di Provinsi Jambi dari tahun 1997 hingga tahun 2015 selalu meningkat. Diawal tahun 2000 pertumbuhan tenaga kerja di Provinsi Jambi sebesar 1,26\% atau sebanyak 1.117.562 jiwa. Jumlah tenaga kerja ini meningkat dibandingkan dengan tahun sebelumnya yang hanya jumlah tenaga kerjanya sebanyak 1.103 .640 jiwa. Untuk setiap tahunnya pertumbuhan tenaga kerja di Provinsi Jambi

\footnotetext{
${ }^{1}$ Dosen FEB Univeritas Jambi

${ }^{2}$ Dosen FEB Univeritas Jambi
}

berfluktuasi. Pada tahun 2011 terjadi pertumbuhan tenaga kerja sebesar $5,5 \%$. Seiring berjalannya waktu pada tahun 2012 jumlah tenaga kerja di Provinsi Jambi mengalami penurunan sebesar $0,79 \%$. Penurunan jumlah tenaga kerja ini terjadi karena adanya penurunan jumlah tenaga kerja pada usia 24-54 tahun khususnya tenaga kerja jenis kelamin laki-laki yang hanya berjumlah 697.516 orang. Terjadinya penurunan ini disebabkan oleh banyaknya tenaga kerja usia 24 tahun keatas mencari pekerjaan di luar Provinsi Jambi. Di tahun berikutnya, yaitu tahun 2013 juga mengalami penurunan sebesar 2,89\%. Pada 2014 dan 2015 pertumbuhan tenaga kerja di Provinsi Jambi kembali meningkat,masing-masing

menyumbangkan sebesar $7,85 \%$ dan $3,98 \%$. Pertumbuhan tenaga kerja ini tidak diimbangi oleh adanya lapangan 
pekerjaan sehingga penyerapan tenaga kerja kurang terserap di sektor - sektor ekonomi. Oleh karena itu, perlu adanya tindakan dari pemerintah guna mengatasi hal tersebut terutama berkaitan dengan

ketenagakerjaan.Pembangunan

ekonomi nasional maupun daerah diwujudkan pada usaha pencapaian tingkat pertumbuhan ekonomi yang tinggi. Indikator ekonomi yang digunakan untuk melihat pertumbuhan ekonomi suatu wilayah atau daerah adalah Produk Domestik Regional Bruto (PDRB). Pembangunan ekonomi di provinsi Jambi masih dihadapkan pada berbagai keterbatasan dan permasalahan di bidang ketenagakerjaan. Pertumbuhan angkatan kerja selalu lebih cepat jika dibandingkan dengan pertumbuhan kesempatan kerja, sehingga masalah pengangguranpun tidak dapat dihindari.

Dilihat dari pertumbuhan ekonomi di Provinsi Jambi pada Tahun 2010 - 2015 berfluktuasi pada kisaran persen. Pertumbuhan ekonomi tertinggi terjadi pada tahun 2011 sebesar 8,58 persen dan terendah pada tahun 2015 sebesar 3,83 persen. Fluktuasi pertumbuhan ekonomi tersebut dapat dilihat pada gambar 1.1. Naik turunnya pertumbuhan PDRB di Provinsi Jambi tersebut tentunya akan berdampak terhadap penyerapan tenaga kerja. Menurut (Simanjuntak, 1998), permintaan akan tenaga kerja didasarkan atas kemampuannya memproduksi barang dan jasa. Besarnya kontribusi PDRB yang dimiliki seharusnya memiliki dampak dalam meningkatnya penyerapan tenaga kerja di provinsi Jambi. Salah satu sasaran utama pembangunan adalah selain meningkatkan pertumbuhan ekonomi disisi lain juga harus mampu menciptakan lapangan kerja baru dalam jumlah dan kualitas yang memadai. Oleh karena itulah, pemerintah senantiasa membuat kebijakan yang dapat meningkatkan taraf hidup pekerja dengan tingkat upah yang layak.

Penerapan kebijakan upah minimum merupakan usaha dalam rangka meningkatkan produktifitas tenaga kerja sehingga tingkat upah rata-rata tenaga kerja dapat meningkat. Produktivitas tenaga kerja ditentukan dalam upah minimum di provinsi Jambi setiap tahun mengalami peningkatan.Upah minimum di Provinsi Jambi selama pada tahun 2010 hingga 2015 berfluktuatif . Pada tahun 2010 upah sebesar Rp.900.000,00 kemudian 2011 upah sebesar Rp.1028.000,00 ini mengalami perkembangan sebesar 14,22 persen. Pada tahun 2012 upah juga mengalami peningkatan menjadi Rp.1142.500,00. Pada tahun ini upah mengalami perkembangan sebesar 11,14 persen. Pada tahun 2015 perkembangan upah juga meningkat menjadi sebesar Rp.1906.650,00 dan mengalami perkembangan sebesar 13,83 persen. Melalui peningkatan upah diharapkan produktivitas tenaga kerja di propinsi Jambi lebih ditingkatkan lagi agar dapat sebanding dengan kenaikan tingkat upah yang ditentukan dalam upah minimum. Dengan adanya kenaikan UMP tiap tahunnya menunjukkan bahwa kebutuhan hidup manusia juga terus mengalami peningkatan.Setelah itu tingginya jumlah penyerapan tenaga kerja dapat dipengaruhi oleh beberapa faktor seperti pengeluaran pemerintah daerah yang diukur dari total belanja langsung dan belanja tidak langsung yang dialokasikan dalam anggaran daerah. Semakin besar Pengeluaran pemerintah daerah yang produktif maka semakin memperbesar tingkat perekonomian suatu daerah (Wibisono,2003).

Pengeluaran pemerintah merupakan salah satu komponen kebijakan fiskal yang bertujuan untuk 
laju investasi, meningkatkan kesempatan kerja, memelihara kestabilan ekonomi dan menciptakan distribusi pendapatan yang merata melalui belanja negara baik itu belanja langsung maupun belanja tidak langsung . Dalam belanja langsung untuk pembangunan yang bertujuan untuk meningkatkan kapasitas produksi dalam proyek yang mengacu pada pertumbuhan ekonomi, pemerataan pendapatan, peningkatan kesejahteraan, dan program yang menyentuh langsung kawasan yang terbelakang.

Berdasarkan sumber data Departemen Keuangan yaitu dalam APBD,realisasi pengeluaran pemerintah di Provinsi Jambi mengalami peningkatan dari tahun ke tahun. Rata rata perkembangan pengeluaran pemerintah daerah Provinsi Jambi selama lima tahun ini sebesar 19,7 persen. Pada 2011 pengeluaran sebesar 1,7 triliun rupiah, di tahun ini mengalami peningkatan sebesar 21 persen dibandingkan tahun sebelumnya. Tahun 2012 meningkat sebesar 46 persen,dimana pengeluaran pemerintah Provinsi Jambi menjadi sekitar sebesar 2,5 miliar. Peningkatan ini terjadi karena meningkatnya belanja langsung dan tidak langsung pada tahun tersebut. Dan pada tahun 2013 pengeluaran pemerintah meningkat juga tetapi peningkatannya tidak terlalu besar hanya sekitar 17,76 persen, yaitu menjadi 3 triliun rupiah. Sedangkan pada tahun 2014 dan 2015 pengeluaran pemerintah Provinsi Jambi sebesar 3,2 dan 3,4 triliun rupiah, yang mengalami peningkatan sebesar 6,39 dan 6,89 persen. Meningkatnya pengeluaran pembangunan ini harusnya mampu untuk menyerap tenaga kerja lebih besar lagi karena pengeluaran ini ditujukan untuk pembiayaan pembangunan sebagai kegiatan pemerintah untuk meningkatkan kesejahteraan masyarakat dan untuk menambah akumulasi modal masyarakat dalam bentuk sarana fisik maupun prasarana dasar.Berdasarkan latar belakang diatas maka penelitian ini menggunakan variabel penelitian diantaranya Produk Domestik Regional Bruto (PDRB) ,Upah Minimun Provinsi (UMP) dan Pengeluaran Pemerintah. Untuk mengetahui pengaruh dari ketiga variabel tersebut, maka peneliti tertarik untuk melakukan penelitian yang berjudul " Pengaruh Produk Domestic Regional Bruto (PDRB), Upah Minimun Provinsi (UMP) dan Pengeluaran Pemerintah terhadap penyerapan tenaga kerja di provinsi Jambi ".

\section{METODE PENELITIAN}

Jenis data yang digunakan adalah Data Sekunder. Data sekunder yang digunakan adalah time series selama kurun waktu 1997-2015. Sumber data yang digunakan dalam penelitian ini berasal dari lembaga - lembaga resmi pemerintah yaitu Badan Pusat Statistik Provinsi Jambi, tulisan - tulisan yang diaanggap relevan dari beberapa media massa yang mendukung dalam penulisan ini.

\section{Analisis deskriptif}

Analisis ini digunakan untuk menjawab rumusan masalah pertama menggunakan metode deskriptif yaitu mengetahui perkembangan PDRB, Upah Minimum Provinsi dan Pengeluaran pemeintah di Provinsi Jambi ,maka untuk mengetahui besarnya perkembangan masingmasing variabel digunakan rata-rata tahunan dengan rumus sebagai berikut (Amir ,2007):

$$
\Delta X n=\frac{X n-X_{t-1}}{X n_{t-1}} x 100 \%
$$

\section{Analisis Kuantitatif}

Analisis regresi berganda digunakan untuk menjawab rumusan masalah kedua yakni menganalisis 
pengaruh ketiga variable terhadap variabel terikat. Bentuk umum persamaan dari analisis regresi linear berganda diformulasikan sebagai berikut (Gujarati,2003) :

$$
Y=\alpha+\beta_{1} X_{1}+\beta_{2} X_{2}+\beta_{3} X_{3}+\mu
$$

Model tersebut ditransformasikan ke dalam analisis regresi berganda model logaritma-linier ( $\log )$ .Persamaan logaritma tersebut berikutnya ditransformasikan ke dalam logaritma natural :

\section{$\log Y=\alpha+\beta 1 \log X 1+\beta 2 \log X 2+\beta 3 \log X 3+\mu$}

\section{Uji Simultan (Uji-F)}

Uji ini dilakukan untuk melihat pengaruh variabel-variabel bebas secara simultan berpengaruh signifikan didalam model Gujarati (1999). Bila Fhitung lebih besar dari F-tabel berarti Ho ditolak, artinya Variabel X secara simultan mampu menjelaskan Variabel Y. Tingkat signifikan yang digunakan adalah $\alpha$ ( $5 \%$ atau 0,05$)$.

\section{Uji Parsial (Uji-T)}

Uji ini dilakukan untuk menguji apakah variabel bebas secara parsial berpengaruh signifikan terhadap variabel terikat dengan asumsi variabel bebas lain dianggap konstan. Dengan tingkat signifikan yang digunakan adalah $\alpha(5 \%$ atau 0,05$)$

\section{Koefisien Determinasi $\left(R^{2}\right)$}

Koefisian determinasi $\left(\mathrm{R}^{2}\right)$ digunakan untuk mengukur seberapa jauh kemampuan model dalam menerangkan variasi variabel dependen. Nilai koefisien determinasi adalah antara 0 dan 1 . Nilai $R^{2}$ yang kecil berarti kemampuan variabelvariabel independen dalam menjelaskan variasi variabel dependen amat terbatas. Nilai yang mendekati satu berarti variabel-variabel independen memberikan hampir semua informasi yang dibutuhkan untuk memprediksi variasi variabel dependent (Ghozali, 2007).

\section{Uji Asumsi Klasik Uji Normalitas}

Uji normalitas merupakan uji yang dilakukan untuk mengetahui apakah dalam sebuah model regresi, variabel dependen, variabel independen, atau keduanya mempunyai distribusi normal atau tidak. Uji Normalitas ini dilakukan dengan cara melihat nilai Probabilitas dari Jarque Berra dalam suatu penelitian. Jika nilai probabilitas Jarque Berra $>\alpha=0,05$ maka Ho diterima, sebaliknya jika nilai Jarque Berra $<\alpha=0,05$ maka H1 diterima.

\section{Uji Multikolinearitas}

Uji multikolinearitas adalah untuk menguji apakah pada model regresi ditemukan adanya korelasi antar variabel bebas (independen). Apabila terjadi korelasi, maka dinamakan terdapat problem multikolinearitas (Ghozali, 2011). Uji multikolinieritas ini dilakukan dengan cara melihat nilai korelasi antar variable independen yang ada dalam penelitian ini. Jika nilai korelasi > 0,10 maka dapat dikatakan data yang ada di dalam penelitian ini terjadi Multikolinieritas.

\section{Uji Autokorelasi}

Uji autokorelasi bertujuan menguji apakah dalam model regresi linear ada korelasi antara kesalahan pengganggu pada periode $\mathrm{t}$ dengan kesalahan pengganggu pada periode $\mathrm{t}-1$ (Imam Ghozali, 2013). Autokorelasi muncul karena observasi yang berurutan sepanjang waktu berkaitan satu sama lainnya. Dalam penelitian ini,peneliti menggunakan pendekatan 
Breusch-Godfrey serial Correlation LM test. Jika nilaia Obs*R-square hasil pengujian serial Correlation LM test lebih kecil dari nilai tabel Chi-Square $\left(X^{2}\right)$ maka lolos dari adanya autokorelasi.

\section{Uji Heteroskedastisitas}

Uji heteroskedastisitas adalah untuk menguji apakah dalam model regresi terjadi ketidaksamaan varians dari residual satu pengamatan ke pengamatan yang lain. Cara untuk mengetahui ada tidaknya heteroskedastisitas adalah dengan melihat grafik plot antara nilai prediksi variabel terikat yaitu ZPRED dengan residualnya SRESID.

\section{HASIL DAN PEMBAHASAN Perkembangan PDRB di Provinsi Jambi}

PDRB merupakan salah satu indikator untuk mengetahui tingkat pertumbuhan ekonomi suatu daerah . Produk Domestik Regional Bruto (PDRB) biasanya diukur dalam bentuk nilai tambah (value added) yang diciptakan oleh sektor perekonomian wilayah tersebut secara total dalam bentuk rupiah. Kondisi pertumbuhan ekonomi yang baik, secara tidak langsung akan mempengaruhi penyerapan pada tenaga kerja..

Dalam kurun waktu tahun 1997 hingga 2015 perkembangan PDRB Atas Dasar Harga Konstan 2000 di Provinsi Jambi cenderung mengalami peningkatan dengan rata - rata perkembangan sebesar 5,49 persen. Peningkatan PDRB tertinggi terjadi pada tahun 2011 sebesar 18 miliar rupiah dengan peningkatan sebesar 8,54 persen dari tahun sebelumnya, hal ini terjadi karena telah memadainya infrastruktur yang dilakukan pada tahun sebelumnya yang membuat performance perekonomian di Provinsi Jambi ikut membaik. Gerak perekonomian yang baik otomatis berpengaruh pada penyrapan tenaga kerja yang pada gilirannya akan dapat mengurangi pengangguran yang terjadi. Pada tahun 2013 seluruh sektor ekonomi mengalami pertumbuhan yang relative menggembirakan. Pertumbuhan tertinggi dicapai oleh sektor konstruksi yaitu sebesar 20,73 persen .Sektor lainnya masing masing tumbuh sebagai berikut : sektor perdagangan, Hotel dan Restoran 12,24 persen; sektor pengangkutan dan komunikasi tumbuh sebesar 8,25 persen ; sektor keuangan, persewaan dan jasa perusahaan tumbuh sebesar 7,88 persen ;sektor Pertanian, Peternakan, Kehutanan dan Perikanan tumbuh sebesar 7,42 persen ; Industri Pengolahan sebesar 5,69 persen; sektor Jasa- jasa tumbuh sebesar 4,80 persen ; serta sektor pertambangan dan penggalian tumbuh sebesar 1,56 persen. Dan pada tahun 2014 mengalami peningkatan sebesar 6,06 persen dari tahun sebelumnya begitu juga di tahun 2015 mengalami peningkatan hanya sebesar 3,83 persen.

\section{Perkembangan UMP di Provinsi Jambi}

Upah merupakan balas jasa tenaga kerja yang diberikan oleh produsen atau perusahaan sebagai imbalan atas hasil jasa tenaga kerja dalam memproduksi barang ataupun jasa. Upah juga merupakan salah satu indikator penting untuk melihat tingkat hidup pekerja. Perkembangan tingkat UMP di Provinsi Jambi selama tahun 1997-2015 terlihat pada tabel di bawah ini .Berdasarkan tabel 5.2 menerangkan bahwa tingkat upah minimum regional di Provinsi Jambi selama periode 19972015 rata-rata mengalami peningkatan sebesar 16,17 persen pertahunnya. Pada tahun 1997 tingkat upah sebesar Rp. 119.500, meningkat menjadi Rp.137.500, di tahun berikutnya .Peningkatan terbesar terjadi pada tahun 2001 yaitu sebesar 41,62 persen , 
hal ini dikarenakan pada tahun awal tahun 2000 hingga 2001 Indonesia mulai bangkit dari krisis moneter yang melanda termasuk juga di Provinsi Jambi. Krisis moneter di tahun 1998 berdampak pada pertumbuhan tingkat upah dan permintaan tenaga kerja sehingga ketika perekonomian mulai pulih, pemerintah terus melakukan evaluasi penetapan upah hingga tahun 2015 agar upah di Provinsi Jambi menjadi lebih baik. Pada tahun 2002 upah juga meningkat sebesar 24,08 persen, tahun 2003 sebesar 28,29 persen.Perbaikan tingkat upah ini secara tidak langsung ikut mendorong peningkatan minat asing guna menanamkan modal mereka di Jambi.

\section{Perkembangan Pengeluaran \\ Pemerintah Provinsi Jambi}

Dalam rangka penyelenggaran otonomi daerah, perencanaan dan pelaksaan pembangunan harus sesuai dengan aspirasi masyarakat (botton up ppalning). Pengeluaran pemerintah (goverment expenditure) merupakan rangkaian kebijakan yang diambil oleh pemerintah daerah guna menjalan fungsinya dalam pembangunan, baik fungsi alokasi, regulasi bahkan regulasi.

Realisasi pengeluaran pemerintah Provinsi Jambi tahun 1997-2015 di menunjukkan peningkatan rata-rata sebesar 21,60 persen. Perkembangan pengeluaran pemerintah tertinggi terjadi tahun 2006 sebesar 50,27 persen. Keadaan lebih disebabkan terjadinya peningkatan belanja tidak langsung sebesar 22,68 persen dibandingkan pada tahun sebelumnya. Untuk diketahui, rata rata realisasi belanja langsung mencapai 89,53 persen dan peningkatan pada realisasi belanja tidak langsung 35,14 persen. Perkembangan terendah terjadi pada tahun 1998 sebesar 4,51 persen, yang terjadi karena dampak krisis ekonomi tahun 1998. Tderjadinya penurunan belanja langsung pada tahun 2000 sebesar 0,58 persen, dipengaruhi oleh turunnya realisasi realisasi belanja langsung di beberapa sektor seperti transportasi 44,03 persen, pembangunan daerah dan pemukiman 26,03 persen serta pertanian dan kehutanan 18,97 persen. Yang tidak terlepas dari menurunannya bantuan alokasi dana dari pemerintah pusat.

\section{Perkembangan Penyerapan Tenaga Kerjadi Provinsi Jambi}

Provinsi Jambi merupakan provinsi yang memiliki jumlah penduduk yang cukup besar. Data pada tahun 2015 tercatat sebanyak 3.402.052 jiwa. Pertumbuhan penduduk alami jelas mempengaruhi peningkatan jumlah penduduk total, apalagi jika ditambah dengan semakin banyaknya penduduk masuk dari daerah atau propinsi Jambi untuk mengadu nasib atau membuka lapangan kerja baru.

Perkembangan jumlah tenaga kerja di Provinsi Jambi selama tahun 1997-2015. Pada periode 1997-2015 jumlah tenaga kerja rata - rata sebesar 2,57 persen per tahunnya. Peningkatan terbesar terjadi pada tahun 2011 yaitu meningkat dari 1.290.706 jiwa menjadi 1.468.658 jiwa, dengan peningkatan 13,79 persen. Peningkatan terkecil terjadi pada tahun 2008 yaitu sebesar 0,92 persen. Pada tahun 2001 terjadi penurunan penyerapan tenaga kerja sebesar 0,47. Kondisi ini terjadi lantaran pada tahun 2001 pertumbuhan ekonomi Indonesia yang mengalami penurunan, yang selanjutnya berdampak negative berupa peningkatan biaya produksi. Jika diamati lebih jauh, jumlah tenaga kerja per sektor di Provinsi Jambi, jumlah orang bekerja di sektor pertanian lebih mendominasi dibandingkan dengan sektor - sektor lainnya, dengan proporsi total mencapai 58,5 persen. Penyerapan tenaga kedua terbesar 
ditempati oleh sektor yang mencapai 3.327.370 jiwa

\section{Uji Hipotesis}

Pengujian Secara Simultan (Uji F)

Berdasarkan hasil penelitian diperoleh nilai probabilitas Fstat sama dengan 0,0000 yang lebih kecil dari taraf nyata 0,05 , nilai Prob F statistik < $\alpha=5 \%$ sehingga keputusan menolak $\mathrm{H}_{0}$ dan menerima $\mathrm{H}_{1}$, artinya variabel Produk Domestik Regional Bruto, Upah Minimum Provinsi dan pengeluaran Pemerintah secara bersama-sama (simultan) berpengaruh signifikan terhadap penyerapan tenaga kerja.

\section{Pengujian Secara Parsial (Uji T)}

Berdasarkan hasil perhitungan, nilai probability PDRB sebesar 0,0002 lebih kecil dari $0,05 \quad(\alpha=5 \%)$. Ini berarti $\mathrm{H}_{1}$ diterima sedangkan $\mathrm{H}_{0}$ ditolak. Dengan kata lain, variabel bebas PDRB berpengaruh positif dan signifikan terhadap variabel terikat penyerapan tenaga kerja pada taraf keyakinan $95 \%$.

Sedangkan UMP, pada taraf $\alpha=$ $5 \%$ dengan tingkat keyakinan $95 \%, \mathrm{H}_{0}$ diterima, sedangkan $\mathrm{H}_{1}$ ditolak. Artinya, variabel bebas UMP tidak signifikan dan berpengaruh negatif terhadap variabel terikat (Penyerapan Tenaga kerja).

Sama halnya dengan variabel bebas pengeluaran pemerintah tidak signifikan dan berpengaruh negatin terhadap penyerapan tenaga kerja pada taraf keyakinan $95 \%$.

\section{Koefisien Determinasi $\left(R^{2}\right)$}

$$
R^{2} \quad \text { sebesar } \quad 0.910043,
$$

menunjukan bahwa proporsi pengaruh variabel PDRB, UMP dan pengeluaran Pemerintah terhadap variabel penyerapan tenaga kerja sebesar 91 persen dapat menerangkan penerangkan variable penyerapan tenaga kerja, sedangkan sisanya 9 persen dipengaruhi oleh variabel lain yang tidak ada di dalam model regresi.

\section{Hasil Regresi}

Nilai koefisien konstanta sebesar 1.767214. Artinya, jika PDRB, Upah Minimum Provinsi (UMP) dan Pengeluaran pemerintah bersifat konstan, maka penyerapan tenaga kerja akan meningkat sebesar 1.767 persen.

Berikutnya, nilai koefisien dari masing masing variabel bebas dapat dilihat sebagai berikut ini.

Nilai koefisien PDRB sebesar 0.6900 yang bertanda positif antara PDRB dengan penyerapan tenaga kerja sektor pertanian. Bila terjadi peningkatan PDRB sebesar 1 persen, maka akan meningkatkan penyerapan tenaga kerja sebesar 0.6900 persen, dengan asumsi variabel yang lainnya tetap atau konstan. Berpengaruhnya PDRB ini terhadap penyerapan tenaga kerja oleh karena di dalam PDRB terdapat sektor sektor atau lapangan usaha yang langsung maupun tidak langsung berpengarauh terhadap penyerapan tenaga kerja, seperti pendekatan perhitungan produksi dan sebagainya-walau antara waktu perhitungan dan hasilnya sebenarnya terdapat lag atau jeda waktu dengan kejadian sebenarnya.

Upah dan pengeluatan pemerintah tidak signikan pengaruhnya terhadap penyerapan tenaga kerja di proponsi Jambi. Berapapun besar pengeluaran pemerintah, tidak mempengaruhi penyerapan tenaga kerja di Provinsi Jambi.

\section{SIMPULAN}

Berdasarkan masalah dan tujuan dari penelitian pengaruh PDRB ,UMP dan pengeluaran pemerintah terhadap penyerapan tenaga kerja di Provinsi Jambi, diperoleh beberapa kesimpulan yaitu:

1. Rata-rata perkembangan PDRB ADHK 2000 periode 1997-2015 
berdasarkan harga konstan sebesar 5,49 persen. Peningkatan PDRB tertinggi terjadi pada tahun 2011 sebesar 18.963,51 miliar dengan peningkatan sebesar 8,54 persen dari tahun sebelumnya. Perkembangan UMP di Provinsi Jambi selama periode 1997-2015 selalu mengalami peningkatan dengan rata-rata peningkatan sebesar 16,17 persen per tahunnya. Peningkatan terbesar terjadi pada tahun 2001 yaitu sebesar 41,62 persen. Rata-rata perkembangan pengeluaran pemerintah mencapai 21,6 persen. Laju perkembangan pengeluaran Pemerintah tertinggi terjadi pada tahun 2006 sebesar 50,27 persen hal ini terjadi disebabkan karena adanya peningkatan pada belanja tidak langsung sebesar 22,68 persen dibandingkan pada tahun sebelumnya dan peningkatan belanja langsung sebesar 64,42 persen.

2. PDRB berpengaruh signifikan terhadap penyerapan tenaga kerja di Provinsi Jambi. Sedangkan variabel UMP dan Pengeluaran pemerintah tidak berpengaruh terhadap penyerapan tenaga kerja di Provinsi Jambi.

\section{Saran}

1. Untuk meningkatkan penyerapan tenaga kerja diharapkan campur tangan pemerintah daerah yang dapat memacu peningkatan Produk Domestik Regional Bruto di setiap sektor - sektor ekonomi sehingga penyerapan tenga kerja meningkat. Pemerintah daerah sudah saatnya perlu mengimplementasikan terwujudnya industry hilir (down strean industry) yang berbasis sumberdaya alam lahan lokal Jambi seperti dari CPO dan karet Jambi.

2. Penerapan kebijakan kenaikan upah harus melalui kajian yang lebih intensif. Kenaikan upah pada satu sisi dapat m,eningkatkan pendapatan masyarakat, namun pada lain sisi sisi bias menjadi masalah berupa keenggaganan para investor baru khususnya guna menanamkan modal mereka di Jambi.

3. Prioritas pengeluaran pemerintah daerah yang tertuju pada kondisi yang seungguhnya dibuhkan oleh masyarakat dan bersifat ekonomi produktif. Kelompok sasaran alokasi dana pengeluaran harus tepat sasaran baik dari sektor atau kegiatan fisik ataupun penelahaan kegiatan non fisik berupa pembinaan dan penyuluhan. Alokasi dana pemerintah daerah harus terintegrasi antara hulu dan hilir (on and off farm integration). Pertimbangan pembangunan dan pemeliharan prasarana dan sarana baik pokok, penunjang dan pelengkap harus diperhitungkan, berbasis kepentingan ekonomi kerakyatan yang berorientasi keunggulan daerah dan daya saing komoditi yang nyata.

\section{DAFTAR PUSTAKA}

Amir. 2007. Dasar - dasar Penulisan Karya Ilmiah. Surakarta: UNS Press. Ariyanto. 2010. Faktor-Faktor yang Mempengaruhi Penyerapan Tenaga Kerja Provinsi Jawa Tengah Tahun 1985-2007. Surakarta. Jurnal Bisnis dan Ekonomi

Andrew E. Sikula. 1992. Manajemen Sumber Daya Manusia. Erlangga. Bandung.

Arsyad , Lincoln.2010. Ekonomi Pembangunan .Yogyakarta : STIM YKPN. Yogyakarta.

Bellante ,Don dan Mark Jackson. 1990. Ekonomi Ketenagakerjaan. Jakarta: Universitas Indonesia

Boediono .1998. Teori Pertumbuhan Ekonomi .BPFE Yogyakarta .Yogyakarta

Budi Utami, Turminijanti. 2009. Pengaruh Upah Minimum Kabupaten, Produk Domestik 
Regional Bruto, Angkatan Kerja dan Investasi terhadap Kesempatan Kerja di Kabupaten Jember. Tesis. Pasca Sarjana Magister Ilmu Ekonomi Universitas Jember.

BPS Provinsi Jambi. 1997 - 2015. Jambi Dalam Angka. Jambi : BPS Provinsi Jambi.

1997-2015.

Statistik Keuangan Provinsi Jambi. Jambi: BPS Provinsi Jambi

.2010-2015

Analisis Pertumbuhan Ekonomi Provinsi .Jambi : BPS Provinsi Jambi .1997-2015.

Indikator Ekonomi Provinsi Jambi. Jambi: BPS Provinsi Jambi

2010

2015.Sakernas Provinsi Jambi. Jambi : BPS Provinsi Jambi

Dimas, Nenik Woyanti. 2009. Penyerapan Tenaga Kerja di DKI Jakarta. Jurnal Bisnis dan Ekonomi. Vol. 16. No. 1. Hal. 31 41

Dumairy, 1997, Ekonomi Indonesia, Erlangga Jakarta.

Ghozali, Imam. 2007. Analisis Multivariate Dengan Program SPSS. Cetakan Empat.Badan Penerbit Universitas diponegoro. Semarang

Ghozali, Imam. 2011. "Aplikasi Analisis Multivariate Dengan Program SPSS". Semarang: Badan Penerbit Universitas Diponegoro.

Gujarati, Damodar. 1999. Ekonometrika Dasar. Jakarta : Erlangga.

Insukindro, 2004, Modul Ekonometrika Dasar, Yogyakarta, FE UGM.

Kuncoro, Haryo. 2002. Upah Sistem Bagi Hasil dan Penyerapan Tenaga Kerja. Jurnal Ekonomi Pembangunan: Kajian Ekonomi
Negara Berkembang Vol. 7, No 1, 2002. ISSN: 1410-2641 hal 4556

Kuncoro, Mudrajad. 2003. Ekonomi Pembangunan .Yogyakarta : LPP AMP YPKN.

Kunarjo.1996. Perencanaan dan Pembiayaan Pembangunan. UI Press. Jakarta

Lin, Steven AY. 1994. Government Spending and Economic Growth, IDEAS.

Mangkoesoebroto, G. (1997), Ekonomi Publik, BPFE, Yogyakarta

Mankiw Gregory, 2006 Pengantar Ekonomi Makro, Edisi Ketiga, Salemba Empat Jakarta.

Nawawi, Hadiri. 2001. Manajemen Sumber Daya Manusia. Bumi Aksara. Jakarta

Nilasari, L. 2007. "Pengaruh Pengeluaran Pemerintah, Investasi, dan Upah Minimum Regional Terhadap Kesempatan Kerja di Jawa Barat studi kasus tahun 1986-2005" [Skripsi]. Sekolah Tinggi Ilmu Statistik, Jakarta.

Peraturan Menteri Tenaga Kerja dan Transmigrasi Nomor 7 Tahun 2013 tentang Upah Minimum

Setianingrum, Erna. 2008. Analisis Faktor-faktor yang Mempengaruhi Penyerapan Tenaga Kerja di Kabupaten Karanganyar Tahun 19912006. Skripsi. FE-UNS. Surakarta.

Simanjutak ,Payaman J. 1998 . Pengantar Ekonomi Sumber Daya Manusia . FEUI, Jakarta.

Suyana Utama, Made. 2008. "Buku ajar Aplikasi Analisis Kuantitatif. Denpasar: Fakultas Ekonomi Universitas Udayana.

Sukirno, Sadono. 2004. Makro Ekonomi Teori Pengantar. Jakarta: PT Raja Grafindo Perkasa.

Sicat, Gerardo P.; Arndt, H.W dan Nirwono, 1991 .Ilmu Ekonomi 
Mikro Untuk Konteks Indonesia. Lembaga Penelitian, Pendidikan dan Penerangan Ekonomi Sosial. Jakarta

Todaro, M.P dan Stephen C.S. 2003.

Pembangunan Ekonomi di Dunia

Ketiga: Edisi Kedelapan.

Jakarta: Erlangga

Undang - undang Republik Indonesia

Nomor 13 tahun 2003 tentang

Ketenagakerjaan.

Wibisono , Dermawan .2003, Riset

Bisnis, Jakarta: PT.Gramedia

Pustaka Utama. 